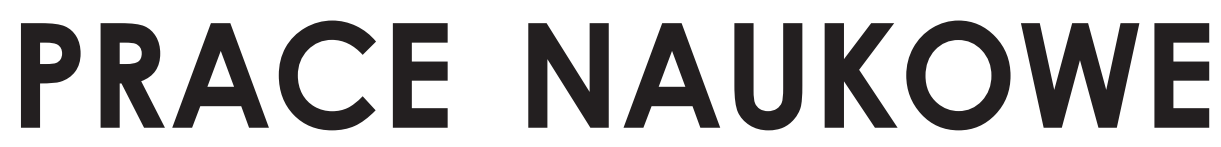
Uniwersytetu Ekonomicznego we Wrocławiu

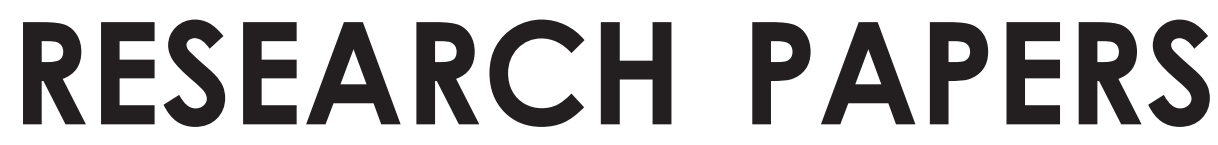
of Wrocław University of Economics

$\operatorname{Nr} 353$

Usługi 2014

Sektor usług - uwarunkowania i tendencje rozwoju

Redaktorzy naukowi Ryszard Kłeczek Anetta Pukas Vy Wydawnictwo Uniwersytetu Ekonomicznego we Wrocławiu
Wrocław 2014 
Redaktor Wydawnictwa: Elżbieta Kożuchowska

Redaktor techniczny: Barbara Łopusiewicz

Korektor: Justyna Mroczkowska

Łamanie: Beata Mazur

Projekt okładki: Beata Dębska

Publikacja jest dostępna w Internecie na stronach:

www.ibuk.pl, www.ebscohost.com,

w Dolnośląskiej Bibliotece Cyfrowej www.dbc.wroc.pl,

The Central and Eastern European Online Library www.ceeol.com, a także w adnotowanej bibliografii zagadnień ekonomicznych BazEkon

http://kangur.uek.krakow.pl/bazy_ae/bazekon/nowy/index.php

Informacje o naborze artykułów i zasadach recenzowania znajdują się na stronie internetowej Wydawnictwa

www.wydawnictwo.ue.wroc.pl

Kopiowanie i powielanie w jakiejkolwiek formie wymaga pisemnej zgody Wydawcy

(C) Copyright by Uniwersytet Ekonomiczny we Wrocławiu Wrocław 2014

ISSN 1899-3192

ISBN 978-83-7695-438-7

Wersja pierwotna: publikacja drukowana

Druk i oprawa:

EXPOL, P. Rybiński, J. Dąbek, sp.j.

ul. Brzeska 4, 87-800 Włocławek 


\section{Spis treści}

Wstęp

\section{Część 1. Pojęcia i modele w marketingu usług}

Katarzyna Dziewanowska: Wpływ działań z zakresu marketingu doświadczeń na postrzeganie usługi edukacyjnej....

Jolanta Mazur, Piotr Zaborek: Czy usługodawcy stosują logikę usługową w marketingu?

Marcin Piglowski: Notyfikacje dotyczące poważnych zagrożeń i pozostałe notyfikacje w systemie RAPEX

Magdalena Rzemieniak: Budowanie tożsamości oferty usługowej w oparciu o wartości niematerialne

Robert Skikiewicz: Determinanty popytu na usługi bankowe na przykładzie kredytów konsumpcyjnych i mieszkaniowych w latach 2004-2013

\section{Część 2. Działalność usługowa jako dziedzina zastosowań zasad i kategorii marketingu}

Dorota Bednarska-Olejniczak: Marketing wewnętrzny w przedsiębiorstwie usługowym......

Monika Boguszewicz-Kreft: Efekt kraju pochodzenia w usługach.

Ema Halavach, Mirosław Zalech: Zmiany w zachowaniach klientów usług turystycznych jako szansa a ryzyko dla biur turystycznych

Martyna Kostrzewa, Grzegorz Zieliński: Specyfika procesów logistycznych w działalności usługowej .....

Anna Lemańska-Majdzik, Piotr Tomski: Konkurencyjność przedsiębiorstwa usługowego. Identyfikacja działań przedsiębiorstw obsługujących rynek nieruchomości

Agnieszka Nowak: Kooperacja i rywalizacja na rynku usług turystycznych w Polsce

Anetta Pukas: Wykorzystanie crowdsourcingu w sferze usług - możliwości i ograniczenia.

Małgorzata Skiert, Krystyna Buchta: Jakość kształcenia na kierunku turystyka i rekreacja w świetle oczekiwań rynku turystycznego. 
Ewelina Sokołowska, Maciej Schulz: Metody ustalania cen produktów na rynku usług w Polsce

Iwona Wilk: Uwarunkowania wyboru ekoagroturystyki jako formy wypoczynku.

Grzegorz Zieliński, Piotr Grudowski, Małgorzata Szymańska-Brałkowska: Oczekiwania interesariuszy usług edukacyjnych w ujęciu relacyjnym

\section{Część 3. E-usługi i innowacje w usługach}

Małgorzata Budzanowska-Drzewiecka, Aneta Lipińska: Motywy wykorzystania aplikacji mobilnych w procesie nabywania dóbr wśród młodych konsumentów.

Joanna Katarzyna Kowalska: Rola internetowych technologii informacyjnych w kreowaniu relacji podmiotów leczniczych z pacjentami na rynku usług zdrowotnych na terenie Dolnego Śląska

Robert Nowacki: Innowacyjność usług w okresie spowolnienia gospodarczego

Aleksandra Radziszewska: Determinanty jakości e-usług na przykładzie bankowości elektronicznej.....

Grażyna Węgrzyn: Zróżnicowanie innowacji w sektorze usług w krajach Unii Europejskiej

Robert Wolny: Rozwój rynku e-usług w Polsce

\section{Część 4. Usługi publiczne}

Anna Brdulak: Strategie rozwoju jednostek samorządów terytorialnych w kontekście świadczonych usług

Danuta Kunecka: Usługi pielęgniarskie w Polsce - uwarunkowania i tendencja zmian

Danuta Kunecka, Dorota Rogalska: Zmiany na rynku usług zdrowotnych a kształcenie na kierunkach medycznych

Dominika Mierzwa: Ocena zarządzania finansami organizacji (na przykładzie zakładu opieki zdrowotnej)

Dariusz Skorupka, Jacek Korona: Gospodarka wodno-ściekowa w aglomeracji kieleckiej - ewolucja koncepcji 


\section{Summaries}

\section{Part 1. Concepts and models in service marketing}

Katarzyna Dziewanowska: Influence of experiential marketing activities on the perception of educational services

Jolanta Mazur, Piotr Zaborek: Is Service Logic practiced by service companies?

Marcin Pigłowski: Serious risk notifications and other notifications in the RAPEX system

Magdalena Rzemieniak: Building an identity of service offer based on intangible assets .....

Robert Skikiewicz: Determinants of demand for banking services - the case of consumer and housing loans in the years 2004-2013

\section{Part 2. Service activities as an application field of principles and categories of marketing}

Dorota Bednarska-Olejniczak: Internal marketing in a service enterprise ...

Monika Boguszewicz-Kreft: Country-of-origin effect in services .....

Ema Halavach, Miroslaw Zalech: Changes in the behavior of customers of tourist services as an opportunity and risk for travel companies......

Martyna Kostrzewa, Grzegorz Zieliński: Specificity of logistic processes in service activities.

Anna Lemańska-Majdzik, Piotr Tomski: Competitiveness of a service company. Identification of activities of enterprises providing services on the real estate market

Agnieszka Nowak: Cooperation and competition on the market of tourist services in Poland

Anetta Pukas: The use of crowdsourcing in services sector - possibilities and limitations

Malgorzata Skiert, Krystyna Buchta: The quality of education at tourism and recreation university studies in the perspective of tourist market expectations

Ewelina Sokolowska, Maciej Schulz: Methods of prices setting of products on the market of services in Poland

Iwona Wilk: Ecoagritourism as a form of recreation selection determinants...

Grzegorz Zieliński, Piotr Grudowski, Małgorzata Szymańska-Brałkowska: Expectations of educational services stakeholders in terms of relations of one with another 


\section{Part 3. E-services and innovations in services}

Małgorzata Budzanowska-Drzewiecka, Aneta Lipińska: Reasons for using mobile applications in the process of acquiring goods among young consumers

Joanna Kowalska: The role of information technology in creating relation between health care providers and patients on the area of Lower Silesia Health Care services market ....

Robert Nowacki: Services innovativeness in the period of economic slowdown

Aleksandra Radziszewska: E-service quality determinants on the example of e-banking services

Grażyna Węrrzyn: Diversification of innovation in the services sector of the European Union countries

Robert Wolny: The development of e-services market in Poland.

\section{Part 4. Public services}

Anna Brdulak: Strategies for the development of local government units in the context of provided services

Danuta Kunecka: Nursing services in Poland - conditions and trend of changes

Danuta Kunecka, Dorota Rogalska: Changes on the health market, and education on medical courses

Dominika Mierzwa: The assessment of organization finance management exemplified by health care institution

Dariusz Skorupka, Jacek Korona: Water-sewage management in the agglomeration of Kielce - the evolution of concept. 


\begin{tabular}{lr}
\hline PRACE NAUKOWE UNIWERSYTETU EKONOMICZNEGO WE WROCŁAWIU \\
RESEARCH PAPERS OF WROCLAW UNIVERSITY OF ECONOMICS & nr 353 • 2014 \\
\hline Usługi 2014. Sektor usług - uwarunkowania i tendencje rozwoju & ISSN 1899-3192
\end{tabular}

\title{
Monika Boguszewicz-Kreft
}

Wyższa Szkoła Bankowa w Gdańsku

\section{EFEKT KRAJU POCHODZENIA W USLUGACH}

\begin{abstract}
Streszczenie: Pomimo że wpływ efektu kraju pochodzenia (country-of-origin effect-COO) na opinie i zachowania nabywcze konsumentów jest jednym z najszerzej zanalizowanych zjawisk w literaturze marketingu, jest on relatywnie słabo rozpoznany w usługach. Wyniki dotychczasowych badań pokazują, że COO jest relewantną kategorią w tym kontekście, jednak wiele problemów badawczych nie zostało podjętych, otwierając interesujący obszar dociekań naukowych, którego rozległość wynika zarówno z wielości typów usług, stopnia natężenia ich specyficznych cech, jak i różnic pomiędzy ich konsumentami pochodzącymi z różnych krajów. W związku z prognozami wzrostowymi transgranicznego handlu usługami, zarówno w skali światowej, jak i dla Polski, wskazana jest konieczność intensyfikacji badań nad COO w ich kontekście. Celem artykułu jest próba wyłonienia luk badawczych i wskazania kierunków badań nad $\mathrm{COO}$ w usługach na podstawie analizy literatury przedmiotu dotyczącej $\mathrm{COO}$ w marketingu i marketingu usług.
\end{abstract}

Słowa kluczowe: efekt kraju pochodzenia, marketing usług.

DOI: $10.15611 / \mathrm{pn} .2014 .353 .07$

\section{Wstęp}

Efekt wpływu kraju pochodzenia na opinie i zachowania nabywcze konsumentów jest jednym z najszerzej analizowanych zjawisk w literaturze międzynarodowego biznesu, marketingu i zachowań konsumentów, jednak analizy dotyczą przede wszystkim produktów materialnych. Przegląd literatury przedmiotu z 20 lat dokonany przez R. Javalgiego i in. (2001) wykazał tylko 19 badań przeprowadzonych w usługach, zaś K.I. Al-Sulaiti i M.J. Baker (1998) w 99 przeanalizowanych publikacjach wskazali ich zaledwie siedem ${ }^{1}$. Należy podkreślić, że efekt kraju pochodzenia w obszarze usług pozostaje nadal relatywnie słabo zbadany².

${ }^{1}$ R.G. Javalgi, B.D. Cutler, W. Winans, At your service! Does country of origin research apply to services, „Journal of Services Marketing” 2001, vol. 15, no. 6/7, s. 568.

${ }^{2}$ Autorski przegląd literatury na podstawie baz publikacji EBSCO i ProQuest (por. W. Czakon, Metodyka systematycznego przegladu literatury, [w:] Podstawy metodologii badań w naukach o zarzqdzaniu, red. W. Czakon, Wolters Kluwer, Warszawa 2013, s. 51). 
Pomimo dominującego znaczenia usług w krajach rozwiniętych, wartość eksportu i importu usług jest znacznie niższa od wartości wymiany towarowej (w krajach UE od dwóch do trzech razy) ${ }^{3}$. Jest to, obok krajowych ograniczeń prawnych, skutkiem specyficznej cechy większości usług, nierozdzielności produkcji i konsumpcji, w wyniku której usługi nie mogą być odseparowane od czynników produkcji. Zatem ich dostępność dla konsumentów z innych państw wiąże się albo z wyjazdem do kraju oferenta, albo z koniecznością przepływu czynników produkcji w celu świadczenia usług. Innym problemem jest niemożność oddzielenia usług od produktów materialnych, z którymi są związane. Należy jednak przypuszczać, że handel transgraniczny będzie rósł $\mathrm{w}$ wyniku tendencji do liberalizowania prawa w tym zakresie, zarówno w skali światowej, jak i europejskiej ${ }^{4}$, postępu technologicznego spowodowanego m.in. komputeryzacją, rozwojem telekomunikacji, dostępem do Internetu umożliwiającym pokonywanie kolejnych barier związanych $\mathrm{z}$ dystrybucją usług oraz rosnącego outsourcingu usług do krajów o niższych płacach $^{5}$.

W obliczu rosnącego znaczenia międzynarodowego handlu usługami konieczna jest intensyfikacja badań nad COO w ich kontekście. Specyfika usług wymaga bowiem zweryfikowania trafności wyników dotychczasowych badań dotyczących produktów materialnych i sprawdzenia, czy wykorzystywane w nich metody badawcze mogą być stosowane również w usługach, ich ewentualnej modyfikacji czy też zaproponowania nowych.

Celem referatu jest przedstawienie dorobku teoretycznego i badawczego dotyczącego $\mathrm{COO}$ w usługach na podstawie przeglądu literatury krajowej i zagranicznej (w szczególności dostępnej w e-bazach EBCSO oraz ProQuest) oraz wskazanie problemów badawczych, które mogłyby być przedmiotem dalszych analiz.

${ }^{3}$ Eurostat, European Commission, 2013, July, http://epp.eurostat.ec.europa.eu/statistics_explained/index.php/International_trade_in_services, 5.11.2013.

${ }^{4}$ Regulują to: Układ Ogólny w sprawie Handlu Usługami (GATS) w ramach Światowej Organizacji Handlu (WTO), w krajach UE zaś Dyrektywa o usługach 2006/123/EC z 12.12.2006, a także większość innych bloków handlowych (np. NAFTA, CETA).

${ }^{5}$ W Polsce ,należy spodziewać się dalszego dynamicznego rozwoju handlu usługami, w tym w szczególności po stronie eksportu usług, w którym będą wykorzystane nowoczesne technologie i wykwalifikowana siła robocza. Można spodziewać się, iż w najbliższych latach średnie tempo wzrostu eksportu usług wyniesie ok. $15 \%$ i będzie o ok. 2 pkt proc. szybsze od dynamiki ich importu, a także będzie wyprzedzało średnie tempo eksportu towarów" (J. Bek (red.), Ocena negocjacji uslugowych po Signalling Conference w dniu 26 lipca 2008 roku, Departament Polityki Handlowej, Ministerstwo Gospodarki, Warszawa 2008, http://www.mg.gov.pl/NR/rdonlyres/0C9E411D-495145DB-B340-05E49489A0B9/47528/SignallingConference_ocenanegocajcjiuslugowychpoSC.doc, 6.11.2013). 


\section{Efekt kraju pochodzenia w marketingu}

Publikacja pióra R.D. Schoolera z 1965 r. $^{6}$ zapoczątkowała badania nad jednym $\mathrm{z}$ najszerzej analizowanych zjawisk $\mathrm{w}$ literaturze marketingu międzynarodowego i zachowań konsumentów - wpływem efektu (wizerunku) kraju pochodzenia na procesy oceny produktów i zachowania nabywcze ${ }^{7}$.

Najogólniej rzecz biorąc, zjawisko to można określić jako wpływ wizerunku danego kraju na ocenę produktów bądź marek z niego pochodzących ${ }^{8}$ i wynikających z niej postaw i zachowań konsumentów ${ }^{9}$. Identyfikacja COO przez konsumentów ma charakter mimowolny ${ }^{10}$, subiektywny i nie zawsze jest trafna, co bywa wynikiem świadomych zabiegów oferentów, którzy starają się poprzez nadawanie odpowiednio brzmiących nazw wywoływać skojarzenia swoich produktów z krajami o mocnym wizerunku (kojarzących się np. z lepszą jakością lub wyższym statusem społecznym $)^{11}$, pozycjonowania ich jako marek globalnych, jak również ukrycia pochodzenia z państw, których wizerunek jest słaby ${ }^{12}$. Trudności w tej materii pogłębia rozmycie kategorii kraju pochodzenia wynikające z procesów globalizacji, których skutkiem jest delokalizacja zakładów wytwórczych, poszczególnych elementów procesów produkcyjnych oraz zmiany właścicielskie. W efekcie kraj pochodzenia staje się wielowymiarową kategorią. Produkty, w których występuje brak zgodności w dwóch (np. kraju producenta i montażu) lub więcej wymiarach, noszą nazwę hybrydowych. $Z$ marketingowego punktu widzenia waga problemów związanych z właściwym przypisaniem kraju pochodzenia wynika z faktu, że moga one rzutować na ocenę produktu i idące za tym decyzje nabywcze ${ }^{13}$.

${ }^{6}$ R.D. Schooler, Product bias in the Central American Common Market, ,Journal of Marketing Research" 1965, vol. 11, s. 394-397.

7 R.A. Peterson, A.J.P. Jolibert, A meta-analysis of country-of-origin effects, „Journal of International Business Studies" 1995, vol. 26(4), s. 83.

${ }^{8}$ A. Figiel, 2004, [za:] K. Liczmańska, Efekt kraju pochodzenia produktu a decyzje nabywcze konsumentów sektora alkoholi wysokoprocentowych, „Roczniki Ekonomiczne Kujawsko-Pomorskiej Szkoły Wyższej w Bydgoszczy" 2010, nr 3, s. 178.

9 T. Sikora, Znaczenie efektu kraju pochodzenia dla komunikacji w biznesie międzynarodowym, „Zeszyty Naukowe SGH” 2008, nr 23, s. 174, Zeszyty_Naukowe_SGH-2008-13-23-173-194.pdf, 10.07.2013; G. Balabanis, A. Diamantopoulos, Gains and losses from the misperception of brand origin: The role of brand strength and country-of-origin image, „Journal of International Marketing” June 2011, vol. 19(2), s. 95.

${ }^{10} \mathrm{Za}$ : S. Rezvani i in., A conceptual study on the Country of Origin Effect on consumer purchase intention, „Asian Social Science” 2012, vol. 8(12), s. 207.

${ }^{11}$ L. Zhou, Z. Yang, M.K. Hui, Non-local or local brands? A multi-level investigation into confidence in brand origin identification and its strategic implications, „Journal of the Academy of Marketing Science" 2010, vol. 38(2), s. 203.

${ }^{12}$ Za: G. Balabanis, A. Diamantopoulos, wyd. cyt., s. 96.

${ }^{13}$ G. Balabanis, A. Diamantopoulos, Brand origin identification by consumers: a classification perspective, „Journal of International Marketing” 2008, vol. 16(1), s. 40; V. Melnyk, K. Klein, F. Völckner, The Double-Edged Sword of foreign brand names for companies from emerging countries, „Journal of Marketing” 2012, vol. 76, s. 22. 
Dotychczasowe badania nad COO dotyczyły przede wszystkim wpływu wizerunku kraju pochodzenia na przekonania i ocenę jakości oferty oraz percepcję jej wartości i ryzyka zakupowego, intencji nabywczych i skłonności do płacenia określonej ceny ${ }^{14}$ oraz były przeprowadzane według wielu cech obejmujących różne produkty, metody i zmienne ${ }^{15}$. Ogólnie rzecz biorąc, badania te wykazały, że wizerunek kraju pochodzenia wpływa na proces oceny i podejmowania decyzji konsumenckich i jest on znaczącym czynnikiem oddziałującym na marketing międzynarodowy ${ }^{16}$.

Ludzie kształtują swoje przekonania odnośnie do danego kraju na podstawie czynników endogenicznych - rozumianych jako mierzalne cechy konsumentów (czynniki kulturowe: etnocentryzm, niechęć do danego kraju, stereotypy, wymiary kultur narodowych według Hofstede oraz czynniki demograficzne) i egzogenicznych (poziom rozwoju gospodarczego kraju konsumentów) ${ }^{17}$. Z kolei przy ocenie produktów konsumenci biorą pod uwagę szereg atrybutów (cues), które można podzielić na wewnętrzne (intrinsic) dotyczące funkcjonalności produktów (np. typ produktu i jego kompleksowość) i zewnętrzne (extrinsic), niewywierające na nią bezpośredniego wpływu, do których obok kraju pochodzenia zaliczamy cenę, markę, sprzedawców i gwarancje. Stanowią one niematerialne własności i można nimi manipulować bez zmiany fizycznych cech produktu. Badania wykazały, że COO jest chętniej wykorzystywane przez konsumentów, gdy wewnętrzne cechy nie są dostępne lub trudne do ocenienia, co ma miejsce w przypadku zagranicznych oraz nowych produktów ${ }^{18}$. Analiza wyników pokazuje, że w tych badaniach, w których wprowadzano tylko jedną wskazówkę, występował większy efekt COO niż wtedy, gdy było ich wiele ${ }^{19}$, a ta ostatnia sytuacja charakteryzuje realne sytuacje rynkowe.

Obok wspomnianych wyżej czynników związanych z produktem (cena, marka, typ produktu i jego kompleksowość, wśród których najczęściej były badane dwa pierwsze) moderatorami wpływu kraju pochodzenia są również indywidualne czynniki związane z konsumentem ${ }^{20}$ : poziom zaangażowania, typ zaangażowania, znajomość produktu i ważność produktu.

${ }^{14}$ Przegląd literatury można znaleźć m.in. w: R.A. Peterson, A.J.P. Jolibert,wyd. cyt.; J.M. Pharr, Synthesizing Country-of-Origin research from the last decade: Is the concept still salient in an era of global brands?, „Journal of Marketing Theory \& Practice” 2005, vol. 13(4); S. Rezvani at al., wyd. cyt.

${ }^{15}$ Należały do nich m.in.: różnorodne cechy dotyczące respondentów, w tym ich typ (studenci/ konsumenci/przedsiębiorcy), narodowość, kraj zamieszkania (rodzinny/emigranci), cechy demograficzne, osobiste doświadczenia, wiedza o kraju i polityczne przekonania, jak również liczba atrybutów w badaniu, wielkości próby, kontekst bodźców (opis produktu/obecność rzeczywistego produktu), kraj bodźców (uwzględniające lub nie kraj respondentów), typy krajów i ich liczba, typy produktów (konsumpcyjne/przemysłowe), ich rodzaje, atrybuty i ich znaczenie dla respondentów (R.A. Peterson, A.J.P. Jolibert, wyd. cyt., s. 88).

16 Za: S. Rezvani et al., wyd. cyt., s. 206-207.

17 J.M. Pharr, wyd. cyt., s. 35-37.

18 Za: J.B. Berentzen et al., Does "Made in ..." also apply to services? An empirical assessment of the Country-of-Origin Effect in service settings, „Journal of Relationship Marketing” 2008, vol. 7(4), s. 394-395.

19 R.A. Peterson, A.J.P. Jolibert, wyd. cyt., s. 83.

${ }^{20}$ J.M. Pharr, wyd. cyt., s. 35-37. 
Nastawienie konsumentów jest wynikiem procesów poznawczych (przekonania konsumentów o rozwoju przemysłowym i zaawansowaniu technologicznym danego kraju przekładających się na jakość i cechy oferowanych przez nie produktów), afektywnych (wartości emocjonalnych i symbolicznych przypisywanych krajowi pochodzenia), konatywnych (pożądany przez konsumenta poziom interakcji z danym krajem) ${ }^{21}$ oraz normatywnych (oddziaływanie norm społecznych, np. inspirowane i nagłaśniane medialnie akcje bojkotu konsumenckiego jako odwet za określone decyzje polityczne) i osobistych (np. rezygnacja z zakupu produktów z krajów, gdzie łamane są prawa człowieka) ${ }^{22}$.

\section{Specyfika usług i jej znaczenie w handlu międzynarodowym}

Specyficzne cechy usług generują wiele problemów dla konsumentów, m.in. niematerialność utrudnia uchwycenie istoty i ocenę jakości oraz rozróżnienie i porównywanie usług świadczonych przez konkurentów, z kolei nierozdzielność produkcji i konsumpcji wiąże się $\mathrm{z}$ zaangażowaniem klienta $\mathrm{w}$ proces produkcji. Zwiększa to postrzegane ryzyko związane z zakupem ${ }^{23}$, tym bardziej że usługi nie można spróbować przed zakupem, nie można jej także zwrócić, gdy okaże się nieodpowiednia, ponadto występują trudności z jej oceną na bazie poprzednich doświadczeń (co wynika z niejednorodności usług).

W przypadku nabywania usług zagranicznych, czy to świadczonych na terenie kraju konsumenta, czy też kupowanych podczas jego wyjazdów, wyżej wspomniane problemy moga powodować szukanie w COO alternatywnego wskaźnika jakości pomagającego zminimalizować postrzegane ryzyko zakupu, z „całym dobrodziejstwem inwentarza" tej wskazówki, tj. z odczuciami związanymi z odbiorem kraju pochodzenia, które mogą być również naznaczone pozytywnymi bądź negatywnymi stereotypami oraz etnocentryzmem usługobiorcy.

\section{Kierunki badań COO w obszarze usług}

W ostatnich latach można zauważyć zwiększone zainteresowanie badaczy zagadnieniami $\mathrm{COO}$ w obszarze usług. Badania te potwierdzają wpływ występowania efektu $\mathrm{COO}$ w usługach, jednak ich ilość i zakres są ciągle niewystarczające i wymagają dalszych analiz w kontekście specyfiki usług. Ponadto badania powinny uwzględniać zróżnicowanie usług obejmujących wiele znacząco różnych ich typów o róż-

${ }^{21}$ Stanowiace trzy komponenty postaw znajdujące swoje odbicie w strukturze wizerunku kraju (M. Laroche i in., The influence of country image structure on consumer evaluations of foreign products, „International Marketing Review” 2005, vol. 22(1), s. 98).

22 D. Maison, 2009, [za:] K. Liczmańska, wyd. cyt., s. 178; G. Balabanis, A. Diamantopoulos, Gains and losses..., s. 96.

${ }^{23}$ C. Bebko, Service intangibility and its impact on consumer expectations of service quality, „Journal of Services Marketing” 2000, vol. 14, s. 9-26. 
nym natężeniu występowania specyficznych cech (w szczególności: niematerialności, nierozdzielności produkcji i konsumpcji oraz niejednorodności). Również wpływ COO na klientów może być różny w zależności od ich krajów pochodzenia, zatem wskazane byłoby dokonanie międzynarodowych porównań. Warto zauważyć, że niewiele badań dotyczyło krajów Europy Wschodniej. Ponadto w niewielu studiach porównywano wyniki badań przeprowadzonych w odniesieniu do większej liczby rodzajów usług, koncentrując się zazwyczaj na ich jednym typie, co czyni problematyczną możliwość uogólnienia ich wyników ${ }^{24}$.

W swojej przeglądowej analizie R.G. Javalgi, B.D. Cutler i W. Winans (2001) dokonali klasyfikacji usług, w kontekście których przeprowadzono badania COO, na trzy szerokie kategorie: 1) usługi podstawowe ${ }^{25}, 2$ ) usługi uzupełniające - towarzyszące sprzedaży produktów materialnych i zwiększające ich wartość oraz 3) międzynarodowe i międzykulturowe porównania usług produkowanych i konsumowanych w poszczególnych krajach ${ }^{26}$.

Wyniki badań pierwszej grupy były zbieżne z rezultatami efektu COO produktów materialnych: klienci preferowali usługi krajowe, z bardziej gospodarczo rozwiniętych krajów lub krajów o mniejszym dystansie kulturowym. Ponadto konsumenci przypisywali dużo większe znaczenie do COO, gdy marka usługi nie była im znana. W kontekście tej grupy usług sugestia cytowanych autorów odnośnie do dalszego kierunku badań jest nadal aktualna - należy sprawdzić, czy wpływ COO jest podobny w każdej z kategorii usług, rozpatrując go według wielu rodzajów ich klasyfikacji (dotychczasowe badania dotyczyły na ogół jednego rodzaju usług). W badaniach dotyczących usług zarówno podstawowych, jak i uzupełniających dołączenie dodatkowych usług wpływało na proces decyzyjny konsumentów. Usługi dodatkowe były również ważniejsze w przypadku bardziej kompleksowych i zaawansowanych technologicznie produktów oraz w przypadku produktów z krajów rozwijających się (gdzie pomagały pokonać obawy klientów). W grupie usług uzupełniających znalazły się cztery badania dotyczące gwarancji lub rękojmi oraz dwie analizy możliwości wymiany lub zwrotu produktu. Jednak katalog usług uzupełniających jest znacznie szerszy, zatem należałoby zbadać, jaki mają wpływ na konsumentów, gdy towarzyszą produktom materialnym i usługom podstawowym.

${ }^{24}$ Pozytywnym wzorem badań przeprowadzonych w dwóch rodzajach usług jest np. M. Michaelis $\mathrm{i}$ in., The effects of country of origin and corporate reputation on initial trust, „International Marketing Review" 2008, vol. 25(4), s. 404-422.

${ }^{25}$ Sześć badań dotyczących: wyjazdów narciarskich, usług asysty eksportowej (B2B), usług prawnych, handlu detalicznego, usług okulistycznych, linii lotniczych.

${ }^{26}$ Przy czym ta ostatnia grupa nie dotyczyła stricte COO, a jej celem było stwierdzenie, czy występują różnice pomiędzy poszczególnymi krajami, w tym jak ich konsumenci oceniają różne aspekty usług w nich produkowanych i konsumowanych. Badania porównawcze wykazały, że konsumenci w znaczący sposób są podobni, jeżeli chodzi o czynniki, które uznają za ważne przy ocenie usług (R.G. Javalgi, B.D. Cutler, W. Winans, wyd. cyt., s. 567, 570, 574). 
Kolejnym obszarem badań nadal słabo reprezentowanym w literaturze przedmiotu są usługi na rynku B2B. Interesujące jest pytanie, czy istnieją różnice dotyczące efektu $\mathrm{COO}$ na tym rynku w porównaniu z rynkiem B2 $\mathrm{C}^{27}$ oraz czy występują różnice we wpływie $\mathrm{COO}$ pomiędzy rodzajami usług.

R.G. Javalgi, B.D. Cutler i W. Winans (2001) wskazali również, że wiele usług biznesowych jest dostarczanych centrali przez jej filie zagraniczne, zatem należałoby zweryfikować efekt $\mathrm{COO}$ w obszarze marketingu wewnętrznego.

Większość badań COO dotyczyła sytuacji, gdy konsumenci dokonywali zakupu obcych usług we własnym kraju, niewiele zaś okoliczności, w których zakup miał miejsce poza granicami kraju ${ }^{28}$. Pojawia się pytanie, czy taka sytuacja zmienia efekt $\mathrm{COO}$ ?

Badania dostarczyły dowodów, że COO wpływa na ocenę jakości ${ }^{29}$ i ryzyka zakupowego ${ }^{30}$ oraz na intencje zakupowe ${ }^{31} \mathrm{w}$ usługach. Jak moderują ten wpływ atrybuty zewnętrzne i wewnętrzne związane z produktem (cena, marka, typ produktu i jego kompleksowość) oraz specyficzne dla usług aspekty (elementy marketingu mix): procesy, aspekty fizyczne i ludzie? Jaki wpływ ma kraj pochodzenia innych współuczestników procesu usługowego? Czy większa liczba wskazówek wpływa na siłę oddziaływania COO? ${ }^{32}$ I z drugiej strony, czy wpływ COO w przypadku oceny poszczególnych elementów kompleksowych usług jest podobny? Czy fakt, iż konsumenci polegają przede wszystkim na właściwościach doświadczanych i „na wiarę”, gdy oceniają jakość usługi, wpływa na znaczenie wskazówki zewnętrznej, jaką jest $\mathrm{COO}, \mathrm{w}$ porównaniu z jego oddziaływaniem w kontekście dóbr materialnych? Czy podobnie jak w przypadku usług materialnych ${ }^{33}, \mathrm{COO}$ ma silniejszy wpływ na ocenę jakości niż faktyczne intencje nabywcze? Czy w przypadku usług (jeżeli tak, to jakich?) COO wpływa na skłonność do płacenia określonej ceny?

${ }^{27}$ G.M. Khan, Internationalization of an Entrepreneurial Services Company from the Arabian Gulf: The case of renaissance services SAOG, „International Journal of Business and Management” 2012, vol. 7(8), s. 42.

${ }^{28}$ Np. E.J. Nijssen, H. van Herk, Conjoining international marketing and relationship marketing: Exploring consumers' cross-border service relationships, „Journal of International Marketing” 2009, vol. 17(1), s. 91-115.

${ }^{29}$ Np. K.A. Wong, V. Folkes, Country-of-Origin Effects on consumers' attributions and word-ofmouth communications about services, „Advances in Consumer Research” 2008, vol. 35, s. 1031.

${ }^{30}$ Np. M. Michaelis i in., wyd. cyt., s. 404-422.

${ }^{31}$ Np. V.P. Khare, K. Popovich, Country of origin of services: are all services created equal?, „Proceedings of the Allied Academies Internet Conference” 2010, vol. 12, s. 116; S. Bose, A. Ponnam, Country of origin effect on services: an evaluation of entertainment, „Managing Leisure” 2011, vol. 16(2), s. 103; J.B. Berentzen et al., wyd. cyt., s. 402; S. Morrish, C. Lee, Country of origin as a source of sustainable competitive advantage: the case for international higher education institutions in New Zealand, „Journal of Strategic Marketing” 2011, vol. 19(6), s. 522.

${ }^{32} \mathrm{~Np}$. jedno z badań wykazało, że zależy to od postrzeganego ryzyka związanego z daną kategorią usług (J.B. Berentzen et al., wyd. cyt., s. 402).

${ }^{33}$ Za: tamże, s. 393. 
Kolejna grupa pytań badawczych wiąże się z usługobiorcami. W jaki sposób czynniki personalne ${ }^{34}$, kulturowe i egzogeniczne moderują wpływ COO? Jaki jest mechanizm oddziaływania COO na intencje zakupu: bezpośredni czy też, podobnie jak w przypadku dóbr materialnych ${ }^{35}$, poprzez całościowe konstrukty związane z marką (jej wizerunek, wartość) czy postrzeganą jakość? Jakie jest znaczenie poszczególnych procesów kształtujących nastawienie konsumentów w kontekście efektu COO w usługach?

Problem identyfikacji właściwego kraju pochodzenia również może występować w usługach. Dotyczy to w szczególności tego ich rodzaju, w których możliwe jest oddzielenie produkcji i konsumpcji usług. I tak hybrydowa usługa może mieć różny kraj pochodzenia marki, miejsca świadczenia, osoby świadczącej i miejsca jej szkolenia ${ }^{36}$. Interesujące w kontekście nastawienia i intencji nabywczych konsumentów są pytania o:

- wpływ stwierdzenia przez konsumentów braku zgodności pomiędzy domniemanym/sugerowanym (wynikającym z brzmienia marki) ${ }^{37}$ a faktycznym krajem pochodzenia,

- wielowymiarowość kraju pochodzenia usług hybrydowych (np. braku zgodności między krajem pochodzenia: właściciela korporacji, marki, pracowników, i w odniesieniu do tych ostatnich: kraju urodzenia, edukacji i zdobywania doświadczenia zawodowego),

- Który/które z tych krajów postrzegane są jako COO?

- Czy występują wzajemne zależności w kierunku i sile oddziaływania wizerunków tych krajów (np. większą siłę oddziaływania ma pozytywny/negatywny silny/słaby wizerunek kraju edukacji niż urodzenia)?

- Czy lingwistyczne brzmienie marki38/nazwiska pracowników (słowiańskie, hinduskie, anglosaskie, niemieckie, inne...) wpływa na percepcję konsumentów?

${ }^{34} \mathrm{~Np}$. L. Long-Yi, Ch. Chun-Shuo, The influence of the country-of-origin image, product knowledge and product involvement on consumer purchase decisions: an empirical study of insurance and catering services in Taiwan, „Journal of Consumer Marketing” 2006, vol. 23, no. 4/5.

35 J.M. Pharr, wyd. cyt., s. 39.

${ }^{36}$ L. Nicolescu, The analysis of conceptual tools for the study of country of origin effect for hybrid offerings, „Management \& Marketing” 2012, vol. 7(1), s. 7.

${ }^{37}$ Por. A. Harun i in., The Concept of Culture of Brand Origin (COBO). A new paradigm in the evaluation of Origin Effect, „International Journal of Academic Research in Business and Social Sciences" 2011, vol. 1(3), s. 282.

${ }^{38}$ Badania wykazały taki związek (L. Salciuviene i in., Do brand names in a foreign language lead to different brand perceptions?, „Journal of Marketing Management” 2010, vol. 26, no. 11/12, s. 1039). 


\section{Podsumowanie}

Wyniki dotychczasowych badań pokazują, że efekt kraju pochodzenia jest relewantną kategorią w międzynarodowym marketingu usług, wpływając na procesy oceny i podejmowania decyzji nabywczych przez konsumentów. Jednak wiele problemów badawczych w omawianej kwestii nie zostało podjętych, otwierając interesujący obszar dociekań naukowych, którego rozległość wynika zarówno z wielości typów usług, stopnia natężenia ich specyficznych cech, jak i różnic pomiędzy ich konsumentami pochodzącymi z różnych krajów. W artykule podjęto próbę wskazania tematów badawczych, które mogłyby wzbogacić dorobek naukowy dotyczący efektu $\mathrm{COO}$ w usługach. Należy zaznaczyć, że nawet jeżeli któreś z proponowanych problemów badawczych zostały podjęte w literaturze przedmiotu (co przy niektórych zagadnieniach zostało wskazane w przypisach), zwykle badania dotyczyły tylko jednego rodzaju usług lub jednostkowego aspektu, co nie daje podstaw do dokonywania uogólnień i wymaga przeprowadzenia badań również w innych kontekstach. Kwerenda źródeł umieszczonych w Internecie wskazuje, iż omawiana tematyka nie została zbadana w odniesieniu do Polski. Ograniczenia i dalsze kierunki badań: Niniejsze opracowanie, dokonane na podstawie analizy dwóch baz publikacji (EBSCO i ProQuest), ze względu na jego cel i ograniczone ramy objętościowe, ma charakter autorskiego przeglądu literatury, dając pogląd na temat dorobku w omawianym temacie. Nie jest on jednak wyczerpujący. Kompleksowe usystematyzowanie literatury naukowej i badawczej po 2000 roku stanowiące kontynuację analizy R.G. Javalgiego i in. byłoby pożądane.

\section{Literatura}

Balabanis G., Diamantopoulos A., Brand origin identification by consumers: a classification perspective, „Journal of International Marketing” 2008, vol. 16(1).

Balabanis G., Diamantopoulos A., Gains and losses from the misperception of brand origin: The role of brand strength and country-of-origin image, „Journal of International Marketing” 2011, vol. 19(2).

Bebko C., Service intangibility and its impact on consumer expectations of service quality, „Journal of Services Marketing" 2000, vol. 14.

Bek J. (red.), Ocena negocjacji ustugowych po Signalling Conference w dniu 26 lipca 2008 roku, Departament Polityki Handlowej, Ministerstwo Gospodarki, Warszawa 2008, http://www.mg.gov.pl/ NR/rdonlyres/0C9E411D-4951-45DB-B340-05E49489A0B9/47528/SignallingConference_ocenanegocajcjiuslugowychpoSC.doc, 6.11.2013.

Berentzen J.B. et al., Does "Made in ..." also apply to services? An empirical assessment of the Country-of-Origin Effect in service settings, ,Journal of Relationship Marketing” 2008, vol. 7(4).

Bose S., Ponnam A., Country of origin effect on services: an evaluation of entertainment, „Managing Leisure" 2011, vol. 16(2).

Czakon W., Metodyka systematycznego przegladu literatury, [w:] Podstawy metodologii badań w naukach o zarzadzaniu, red. W. Czakon, Wolters Kluwer, Warszawa 2013. 
Eurostat, European Commission, 2013, July, http://epp.eurostat.ec.europa.eu/statistics_explained/index.php/International_trade_in_services, 5.11.2013.

Harun A., Wahid N.A., Mohammad O., Ignatius J., The Concept of Culture of Brand Origin (COBO). $A$ new paradigm in the evaluation of origin effect, ,International Journal of Academic Research in Business and Social Sciences" 2011, vol. 1(3).

Javalgi R.G., Cutler B.D., Winans W., At your service! Does country of origin research apply to services, ,Journal of Services Marketing” 2001, vol. 15, no. 6/7.

Khan G.M., Internationalization of an Entrepreneurial Services Company from the Arabian Gulf: The case of renaissance services SAOG, „International Journal of Business and Management” 2012, vol. 7(8).

Khare V.P., Popovich K., Country of origin of services: are all services created equal?, „Proceedings of the Allied Academies Internet Conference" 2010, vol. 12.

Laroche M., Papadopoulos N., Heslop L.A., Mourali M., The influence of country image structure on consumer evaluations of foreign products, ,International Marketing Review” 2005, vol. 22(1).

Liczmańska K., Efekt kraju pochodzenia produktu a decyzje nabywcze konsumentów sektora alkoholi wysokoprocentowych, „Roczniki Ekonomiczne Kujawsko-Pomorskiej Szkoły Wyższej w Bydgoszczy" 2010, nr 3.

Long-Yi L., Chun-Shuo Ch., The influence of the country-of-origin image, product knowledge and product involvement on consumer purchase decisions: an empirical study of insurance and catering services in Taiwan, „Journal of Consumer Marketing” 2006, vol. 23, no. 4/5.

Melnyk V., Klein K., Völckner F., The Double-Edged Sword of foreign brand names for companies from emerging countries, ,Journal of Marketing” 2012, vol. 76.

Michaelis M., Woisetschläger D.M., Backhaus Ch., Ahlert D., The effects of country of origin and corporate reputation on initial trust, „International Marketing Review” 2008, vol. 25(4).

Morrish S.C., Lee C., Country of origin as a source of sustainable competitive advantage: the case for international higher education institutions in New Zealand, „Journal of Strategic Marketing” 2011, vol. 19(6).

Nicolescu L., The analysis of conceptual tools for the study of country of origin effect for hybrid offerings, „Management \& Marketing” 2012, vol. 7(1).

Nijssen E.J., Herk H. van, Conjoining international marketing and relationship marketing: Exploring consumers' cross-border service relationships, „Journal of International Marketing” 2009, vol. 17(1).

Peterson R.A., Jolibert A.J.P., A meta-analysis of country-of-origin effects, „Journal of International Business Studies" 1995, vol. 26(4).

Pharr J.M., Synthesizing Country-of-Origin research from the last decade: Is the concept still salient in an era of global brands?, „Journal of Marketing Theory \& Practice” 2005, vol. 13(4).

Rezvani S. et al., A conceptual study on the Country of Origin Effect on consumer purchase intention, „Asian Social Science” 2012, vol. 8(12).

Salciuviene L., Ghauri P.N., Streder R.S., De Mattos C., Do brand names in a foreign language lead to different brand perceptions?, ,Journal of Marketing Management” 2010, vol. 26, no. 11/12.

Schooler R.D., Product bias in the Central American Common Market, „Journal of Marketing Research" 1965, vol. 11.

Sikora T., Znaczenie efektu kraju pochodzenia dla komunikacji w biznesie międzynarodowym, „Zeszyty Naukowe SGH” 2008, nr 23.

Wong K.A., Folkes V., Country-of-Origin Effects on consumers' attributions and word-of-mouth communications about services, „Advances in Consumer Research” 2008, vol. 35.

Zhou L., Yang Z., Hui M.K., Non-local or local brands? A multi-level investigation into confidence in brand origin identification and its strategic implications, „Journal of the Academy of Marketing Science" 2010, vol. 38(2). 


\section{COUNTRY-OF-ORIGIN EFFECT IN SERVICES}

Summary: The impact of country-of-origin (COO) on the opinion and consumer behavior has been one of the most widely analyzed phenomena in the marketing literature. However, it is relatively weakly researched in the area of services. In connection with the growth prospects of international trade in services, both globally and in Poland, a need to intensify research on $\mathrm{COO}$ in this context is indicated. The purpose of this paper is an attempt to identify research gaps and indicate directions for further studies on $\mathrm{COO}$ in services basing on an analysis of the literature of marketing and marketing services.

Keywords: country-of-origin effect, services marketing. 